\begin{tabular}{|c|c|c|}
\hline \multirow[t]{3}{*}{$\mathbb{H}^{E M_{A}}$} & KEMAS 15 (2) (2019) 171-178 & OREMAS \\
\hline & Jurnal Kesehatan Masyarakat & 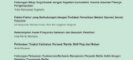 \\
\hline & http://journal.unnes.ac.id/nju/index.php/kemas & $\overline{E-m=-}$ \\
\hline
\end{tabular}

\title{
Environmental Sanitation and Hygiene on Waste Collector in TPA Piyungan Bantul Yogyakarta
}

\author{
Jasas Munandar, Surahma Asti Mulasari ${ }^{\bowtie}$ \\ RS Islam Yatofa, Lombok \\ Faculty of Public Health, Universitas Ahmad Dahlan Yogyakarta
}

\begin{tabular}{l} 
Article Info \\
\hline Article History: \\
Submitted March 2018 \\
Accepted October 2019 \\
Published November 2019 \\
\hline Keywords: \\
Hygiene, Sanitation, \\
Environment, Garbage, TPA \\
\hline DOI \\
https://doi.org/10.15294/ \\
kemas.v15i2.13801
\end{tabular}

\begin{abstract}
A garbagemen involved directly with garbage, it causes a garbagemen have injuried oftenly when they do their duty. Based on center of worker trans department Jakarta, the injury case causes has 81.169. A garbagemen risk, highly to influence. This is a descriptive kualitative research, the subject are garbagemen who lived in TPA Piyungan and people who involved to manage TPA Piyungan, Bantul Yogyakarta. Research use observed method and In-Depth Interview method. Data analyzed as kualitative descriptive. Data collected by triangulasi source technique.The result that sanitation and hygienic environtment and how to keep the environtment clean, and to maintain the risk environment work on the garbageman area is deficient. The suitability between sanitation and hygiene environment on the garbagemen still need to improve. Financing is the problem of the garbagemen, hygiene environment on garbagemen work area's very deficient, that things happened too for willingness and act to create a healthy environment.
\end{abstract}

\section{Introduction}

Waste landfill (TPA) is a physical facility in the form of a place that is used to quarantine municipal waste safely. The presence of TPA often creates a dilemma. TPA activities cause inconvinience effects, such as noise, scattered garbage, dust, odor, and vector animals. There are countless invisible threats, such as the possibility of a gas explosion due to inadequate processing. Furthermore, waste also has the potential to cause social conflicts with surrounding communities due to land control by groups of people living from scavenging.

Garbage is anything that is no longer desired by those who have and is usually solid (Soemirat, 2011). The impact of waste is very large. Garbage that continues to grow and is not managed properly can cause problems for the government, society, health and the environment (Mulasari dan Sulistyawati, 2014). The impact of improper waste disposal can hamper the building of good and healthy environment (Riduan, 2012).

Hygiene and environmental sanitation are the supervision of the physical, biological, social and economic environment that affects human health, a useful environment is increased and reproduced, while the harmful ones should be repaired or eliminated (Entjang, 2000). WHO states that the mortality rate, the high ratio of sick people (morbidity), and the frequent occurrence of epidemics, occur in a place with poor environmental hygiene and sanitation. In that place there were many 
flies, mosquitoes, irregular sewage and garbage (Entjang, 2000).

Hygiene is a preventative health effort that focuses on individual health, as well as personal human health (Rakhmawati dan Hadi, 2015). In hygiene there is concepts of treatments that positively affect human health. Health is related to the level of physical, spiritual, and social well-being (Fajriansyah, 2017).

The environment is everything that exists around humans, whether in the form of living things, inanimate objects, real objects, or abstracts, including other humans (Soemirat, 2011). Environment has a big role in influencing the degree of public health. (Gracia et al., 2018). Waste that is not handled properly will result in an adverse change in environmental balance. Environmental pollution by garbage is harm, both for humans and the environment (Hariyanto and Ariyani 2011).

Piyungan Landfill is the final landfill for the Yogyakarta, Bantul and Sleman. In the Piyungan landfill area there are many garbage collector and scavenger. They mostly come from outside Yogyakarta. Environmental management carried out by the government includes coordinating the presence of collectors and scavengers in the Piyungan landfill environment. Their existence cannot be ignored because they affect the waste management system and the environment at Piyungan Landfill. They help reduce the volume of inorganic waste, thus extending the life of Piyungan landfill. Collectors and scavengers who are active in the Piyungan Landfill cause environmental conditions to be unorganized and dirty. Poor environmental conditions will have a return to the health of collectors and scavengers. Based on these problems, the researchers are interested in knowing the environmental conditions where garbage collection activities in Piyungan Landfill are, so that later it can minimize the risk factors causing disease to the collectors.

\section{Method}

This research is a qualitative research conducted in January 2017. The research was conducted at Piyungan Landfill RT 03, Ngablak Hamlet, Sitimulyo Village, Piyungan District, Bantul Regency, Yogyakarta. The data collection technique used was purposive sampling technique. The subjects of this study were garbage collectors (six people) with criteria of ones who lived and settled in the Piyungan landfill area, both men and women from morning to night and were assisted as resource persons. The management officer of the Piyungan Bantul landfill (one person), as well as the Indonesian plastic recycling association (ADUPI), were willing as informants (one person). While the object of the research is the Piyungan landfill waste collection house environment. The variable in this study is single variable, namely the tourism and hygiene environment in garbage collectors in Piyungan Bantul TPA, while the research plan includes Environmental Sanitation and hygiene in garbage collectors is assistance for environmental research where place and equipment can cause disease or health problem. Conformity between environmental protection requirements and hygiene of garbage collectors at Piyungan Bantul TPA in Yogyakarta with peraturan Pemerintah Republik Indonesia No. 66 year 2014 concerning environmental health, hygiene management, workplaces, environmental assistance, safety, security, and comfort to be occupied as workplaces. This study used the method of observation and indepth interviews. The instruments used were interview guides, human instruments and checklists used in accordance with the Peraturan Pemerintah Republik Indonesia Number 66 Year 2011 concerning Environmental Health to determine environmental sanitation and hygiene in garbage collectors at the Piyungan Bantul landfill in Yogyakarta. The tools used in this study are notebooks, tape recorders and cameras / cellphones. The type of data to be taken were primary data and secondary data. Primary data was obtained directly from the subject of the research while the secondary was general area review, floor plan of the location of garbage collectors in the Piyungan Bantul TPA Yogyakarta obtained from books and literature that can be used as supporting material. The data were collected through interviews, observation, and visual images. This research used the method of data analysis model by Miles and Huberman (1984) where activities in the analysis of qualitative data were carried out 
interactively and continuously until finished so that the data is saturated. The data were analyzed qualitatively and to ensure the validity, the source triangulation technique was carried out. Source triangulation was conducted by checking some data that has been obtained through several sources in each research which is seen from the results of interviews on all research subjects. From the data obtained from the source or subject, it was then analyzed by the researcher so as to produce conclusions and subsequently the agreement (member check) with the person who is the source of the information (Moleong, 2012).

\section{Result and Discussion}

The condition of environmental sanitation and hygiene in garbage collectors in the Piyungan Bantul landfill in Yogyakarta was observed based on the Peraturan Pemerintah Republik Indonesia Number 66 year 2014 concerning Environmental Health with Indicators for assessing environmental sanitation and hygiene conditions. The indicators taken are the physical quality of water, water sources, waste management, bath wash toilet facility (MCK), buildings / buildings, and hazardous environmental exposures. A summary of the results of observations can be seen from the following table:

The results obtained indicated that the provision of clean water was as expected. Most of the residents in the Piyungan landfill had used drill wells provided by the local government. Drilled well water was used for bathing, washing, cooking and other activities, while drinking water consumed commercial water. The irrigation system was carried out using pipes that were connected and flowed to people's homes. The physical quality of water in the Piyungan landfill environment from observations showed that the water was odorless, tasteless, and colorless. The water source was closed so that it was protected from pollutant sources. The physical quality of water and water sources in this research was in accordance with quality standards, namely water that is odorless, tasteless, and colorless. This result is in line with previous research which stated that for physical parameters of well water in the Piyungan landfill area all have met the quality standards (Suhartini, 2008). The results of this research are also consistent with one in the City of Tunis, namely the quality of water (physical, chemical) near the location of solid waste disposal in conformance with the drinking water standard of the WHO (Abdelwaheb et al, 2012). Another research in Tuminting Manado District showed different results from the one conducted, namely that the physical parameters of water quality around the Tuminting Manado District were unconform with the water quality standard requirements (Tambunan et.al., 2015). Similar findings were also found in the study in the city of Padang, namely the quality of well water around the TPA based on bacteriological parameters not suitable for consumption (Wulandari and Nasir, 2014).

The good physical quality of water in the Piyungan landfill area may be caused by collectors in the Piyungan landfill using water from bore wells provided by the local

Table 1. Conformance of garbage collectors' environmental sanitation and hygiene conditions in the Piyungan Bantul landfill in Yogyakarta with the Peraturan Pemerintah Republik Indonesia Number 66 year 2014 concerning Environmental Health

\begin{tabular}{ll}
\hline Observed object & Result \\
\hline Water Physical Quality & 6 (six) conform location \\
Water Source & 6 (six) conform location \\
Waste Management & 3 (three) of 6 (six) conform location \\
Bath Wash Toilet Facility (MCK) & 6 (six) conform location \\
Building & 6 (six) unconform location \\
Hazard Environmental Exposure & 6 (six) unconform location \\
Safety Equipment & 6 (six) conform location \\
\hline
\end{tabular}

Source : Primary Data, 2017 
government. One of the factors that affect water quality can be viewed from the type of well. Drill wells are made by drilling deeper layers of groundwater so that they are slightly affected by contamination (Munfiah et.al., 2013).

Other results in this research indicate that three out of six business locations of garbage collectors had provided trash bins, but the trash cans used were still open rubbish bins, while the other three locations did not provide trash bins, even the waste generated was only disposed to empty land around their residence. People who do not have trash cans tend to dispose of their garbage carelessly. This is in line with previous research which stated that the absence of trash cans 3.7 times gave the impact of people littering (Istiqomah, 2015). This phenomenon is also strengthened by research in Abeokuta, Nigeria. Most of the population in Abeokuta, Nigeria does not have a landfill, so the population does not do the garbage separation, dispose of litter in the environment around the house, and only a few residents do waste recycling (Achi et al, 2012).

Environment is a matter that is oftenly unnoticed in the garbage collectors' environment in Piyungan Landfill. Garbage collectors have a role to collect the waste garbage from the scvengers. The activities of collectors are to weigh and package the garbage that has been grouped according to its type, then sell it to outside agents who come to buy the sorted waste. Not all waste can be sold because scavengers do not carry out careful sorting so that there is a lot of waste left over, one of which is plastic/crackle. Based on information from the ADUPI (Indonesian Plastic Recycling Association), it was revealed that plastic waste scattered on the road near waste management was caused by crackle type plastic waste which was considered not feasible because it did not have a selling value.

The trash found around the Piyungan landfill in the form of cracked garbage is different from that found in Jombang. The trash found around TPA in Jombang comes from vegetable / fruit / leaf waste, paper waste, wood waste where the type of waste is organic waste. Inorganic waste such as plastic waste, cloth waste, rubber waste, metal / iron waste, glass waste is rarely found because a lot of garbage has been selected by scavengers when in garbage disposal sites (TPS) before being transported to landfill waste (Fidiyawati dan Sudarmaji, 2013).

The behavior of littering is inseparable from environmental influences. This is in line with previous research which stated that behavior occurs due to several reasons, including the lack of awareness of the community to maintain the environment (Kusrini, 2015). Even when a temporary waste disposal site has been provided in its environment, the community is still not orderly in the time or place to dispose of garbage (Mulasari et al, 2016). Other studies in Korea also stated that attitudes towards the environment are significantly related to the behavior of waste recycling and waste treatment (Lee and Paik, 2011)ranking the third-highest in the world [1]. In 1995, the Korean government implemented a volume-based waste fee system (unit pricing system. In Nigeria, the ignorance of the population is one of the contributing factors to the problem of waste management (Fafioye and Jhon-Dewole, 2013).

Provision of MCK facilities at the location has been provided by all garbage collectors at Piyungan Landfill, but the cleanliness is not well maintained. MCK is always associated with sanitation problems (Arini, 2016). The condition of poor sanitation is certainly endangering the community itself and the impact will cause various types of diseases (Suhadi dan Namara, 2016). The results of interviews and observations showed that there was still a lack of awareness of garbage collectors in maintaining the cleanliness of MCKs and hygiene themselves such as not washing hands and rarely cleaning the toilet.

MCK facilities such as unhealthy and unclean latrines can be a source of bacterial spread in human faeces, which are carried by intermediary animals such as insects or through direct contact, so that bacteria can enter the body (andansari, 2013) (Wandansari, 2013). Enteropathogens or pathogens commonly found in human skin such as Staphylococcus aureus, can be easily transmitted between individuals by touching the toilet surface (Flores dkk, 2011). Maintaining the cleanliness of hands, nails and feet is an important aspect in preserving the health of an individual. Germs 
can be carried through hands, nails, and dirty feet (Ptatama dan Prasasti, 2017).

This research is in line with one in Bangladesh where the level of personal hygiene of scavengers is unsatisfactory. As many as $18.0 \%$ had MCK but not hygienic, most $69.3 \%$ of scavengers were found with long and dirty finger nails. Only $8.0 \%$ of scavengers wash their hands with soap after defecation and 17.3\% of them take a bath every day. During work, all scavengers maintain contact as usual such as shaking hands, smoking, eating street food without washing hands. Their poor personal hygiene practices may also be a potential risk factor for their disease (Rifat et al, 2018).

Observation results show the condition of the building of garbage collectors around the Piyungan landfill looked fragile and dirty. Some collectors had provided warehouses / buildings for storage as well as places for steaming activities, but were still not clean and not qualified for a healthy work environment. Most workplaces / buildings were made of wood and bamboo, the condition of old and fragile support poles can endanger workers' safety if not replaced with stronger materials. The physical condition of the work environment can cause harm directly or indirectly to work health and safety. The quality of the work environment that is low physically and mentally can cause non-productive pressure on workers so that there are many events that disrupt work activities(Oesman, 2014).

The building of garbage collectors does not sufficient the requirements for a healthy work environment due to economic constraints so that residents in the landfill area cannot provide proper facilities. The location of the house that was standing right on the land of the disposal made the house environment should not be used as a settlement because it was dangerous (Aida dan Syahbana, 2014). This condition is almost the same as the condition in Tuminting Manado where the average scavenger houses there, are made of plywood with a size of $20 \mathrm{~m}^{2}$ to $42 \mathrm{~m}^{2}$ (Kawalo dkk, 2016).

Hazardous environmental exposurein the collector's environment in the Piyungan Bantul landfill in Yogyakarta was not appropriate. It still smells bad in the environment around the Piyungan Bantul landfill. The smell came from the transportation process or from a pile of garbage spreads carried by the wind to the surrounding area. Odor emissions from the landfill site were caused by anaerobic degradation of the waste (Bortone dkk, 2012). In addition to the smell of dust found in many places of garbage collection. The workplace of garbage collectors who were still grounded causes the floor to become dusty, and the risk of disease occurring. This is in line with previous research which stated that there was an increasing trend in cough symptoms in one month due to increased dust and air pollution (Sinolungan, 2009).

Stacks of garbage that are not properly arranged can trigger vector breeding. Interviews showed that there were many disease vectors, namely cockroaches, flies and mice at the location of garbage collection, but all the informants said that they never carried out vector control because they were too difficult. Research in Jombang states that there are residents around TPA who experience health problems due to the presence of disease vectors $t$ (Fidiyawati dan Sudarmaji, 2013)

Collectors at Piyungan Landfill in carrying out their work activities already use PPE (personal protective equipment). PPE used include shoes, gloves, masks, long sleeves, and trousers. Other research in the city of Yogyakarta stated the same thing, namely garbage officers when working using PPE such as gloves, safety shoes, safety helmets, and work clothes (Mulasari dan Maani, 2013). In Narkhon Ratchasima, Thailand scavengers also use PPE such as gloves, hats, shoes, longsleeved clothes, and trousers when working (Thirarattanasunthon et al, 2012)reduce, and recycle waste, the appropriate management of municipal solid waste (MSW.

Awareness of collectors in Piyungan Landfill on the importance of using PPE when working can be said to be good. They are aware of the risk of danger from their work. One of the collectors' awareness is obtained from counseling provided by the health office. The counseling material given was about environmental health and personal hygiene. Garbage collectors in the Piyungan landfill area have a good level of knowledge about the use 
of PPE. The use of PPE when in contact with garbage can reduce the risk of diseases due to garbage such as skin diseases.

Research at Wukisari temporary landfill, Gunung Kidul stated that there was a significant relationship between the use of PPE and the incidence of skin diseases (Novianingrum and Mulasari, 2017). The research in Kediri TPA showed that the use of PPE in scavengers had a significant relationship to skin disease (Indasah et al, 2016). Research in Nakhon Ratchasima Province, Thailand stated that scavenger groups who were given interventions using PPE during work and occupational safety health training showed significant differences before and after being given interventions for occupational safety hazards compared to scavengers who were not given intervention (Thirarattanasunthon et al, 2012).

The government participates in the management of garbage collectors in the Piyungan Landfill. The environmental management around the Piyungan Landfill is carried out by the Landfill Manager coordinated by the Office of Public Works, Energy and Mineral Resources D.I. Yogyakarta. The government has a stake in creating a healthy and clean environment in a garbage collector's environment. The government has provided supporting facilities such as the provision of public toilets, electricity, and road improvements.

The government's role in urban waste management also occurs in Kadipiro Surakarta City polling station. Waste management is carried out by processing organic waste into compost and inorganic waste brought to the Waste Bank to be sorted back according to its type, then sold to a recycling plant. B3 hazardous waste is reprocessed with special chemical processes or to make certain products (Aryenti dan Kustiasih, 2013). In the City of Port Harcourt, Nigeria, waste management is carried out with the basic principles of waste management (Binafeigha and Enwin, 2017). In Malaysia, the current waste management policy is carried out using the foundation to build a healthy and sustainable waste management system (Fauziah and Agamuthu, 2012). The obstacle faced by the government in managing the landfill environment is the lack of awareness of citizens in the utilization of facilities properly, residents are still careless and ignore the cleanliness of the available facilities.

\section{Conclussion}

The condition of environmental sanitation and hygiene in the Piyungan Bantul landfill in Yogyakarta is still unproper. Conformity between environmental sanitation conditions and hygiene with Peraturan Pemerintah Republik Indonesia Number 66 Year 2014 is quite good, but it is very lacking in maintaining and caring for it, the economy is a major obstacle in completing the availability of supporting sanitation. The management of cleanliness of the workplace is quite good, but still a lack of willingness / action to create a healthy environment and personal hygiene of collectors as well as avoiding things that can disrupt health.

Based on the results above, it is recommended that garbage collectors increase their awareness of the provision of supporting facilities or environmental hygiene in order to improve the health of themselves, their families, or the surrounding community. In addition to the local government to pay more attention to small workers such as garbage collectors to help provide supporting facilities so that workers or local communities are not constrained in fulfilling sanitation and environmental hygiene requirements, in order to improve community health status or community health.

\section{References}

Abdelwaheb, A., Moncef, Z., Dhia, B.H., 2012. Landfill Leachate Generation and Its Impact on Water at an Urban Landfill (Jebel Chakir, Tunisia). Hydrology: Current Research, 3(2), pp. 1-5

Achi, H. A., Adeofun, C.O., Gbadebo, A.M., Ufeogbune, G.C., Oyedepo, J.A., 2012. An Assessment of Solid Waste Management Practices in Abeokuta, Southwest, Nigeria. Journal of Biological and Chemical Research, 29(2), pp.177-188.

Arini, A.P., 2016. Penyebaran Paham Poop Culture Melalui World Toilet Organization Di Swiss Jurnal JOM FISIP, 4(1), pp.1-12.

Aryenti., \& Kustiasih, T., 2013. Kajian Peningkatan Tempat Pembuangan Sampah Sementara Sebagai Tempat Pengolahan Sampah Terpadu. Jurnal Permukiman, 8(2), pp.89-97.

Binafeigha, T.R., Enwin, A., 2017. The State of Solid Waste Management in Port Harcourt City, 
Nigeria. American Journal of Civil Engineering and Architecture, 5(4), pp.160-166.

Bortone, I., Carillo, S., Nardo, A.D.M., Natale, M.D., Musmarra, D., 2012. Mitigation of the Odorous Impact of a Waste Landfill Located in a Highly Urbanized Area. Journal Chemical Engineering Transactions, 28, pp.229-234.

Entjang, I., 2000. Ilmu Kesehatan Masyarakat. Bandung. PT. Citra Aditya Bakti.

Fafioye, O.O., Jhon-Dewole, O., 2013. A Critical Assessment of Waste Management Problems in Ibadan South-West Local Government Area, Ibadan, Nigeria. Greener Journal of Environmental and Management Studies, 2(2), pp.060-064.

Fajriansyah., 2017. Perilaku Hygienitasi Pengelolaan dan Pembuatan Kue Home Industri Rumahan di Desa Lampanah Kecamatan Seulimeum. Jurnal AcTion: Aceh Nutritionl, 2(1), pp.13-17.

Fauziah, S.H., \& Agamuthu, P., 2012. Trends in Sustainable Landfilling in Malaysia, A Developing Country. SAGE Journals, 30(7), pp.656-663.

Fidiyawati, L., \& Sudarmaji., 2013. Pengelolaan Tempat Pemrosesan Akhir Sampah Kabupaten Jombang dan Kesehatan Lingkungan Sekitarnya. Jurnal Kesehatan Lingkungan, 7(1), pp. 45-53.

Flores, G.E., Bates, S.T., Knights, D., Lauber, C.L., Stombaugh, J., Knight, R., 2011. Microbial Biogeography of Public Restroom Surfaces. Journal Plos One, 6(11). pp.e28132

Souisa, G.V., P, Zulkiflin., \& Vauza., 2018. Sosialisasi Dampak Lingkungan Terhadap Penularan TB dan Filariasis di Negeri Hatuhenu Kecamatan Amahai Kabupaten Maluku Tengah. Jurnal ABDINUS, 1(2), pp.152-158.

Hariyanto \& Ariyani., 2011. Pengelolaan Sampah Di Kota Semarang Untuk Menuju Kota Bersih. Jurnal Forum Ilmu Sosial, 38(1). pp.55-62.

Indasah., Maula, N.Z., \& Prima, D.K., 2016. Relationship of Behaviour in the Use of Personal Protective Equipment (APD), Eating a Healthy and Balanced, and Personal Higiene to Health Status of Skin on Scavengers in Tpa Kediri. Journal of Applied Environmental and Biological Sciences, 6(2). pp.1-5.

Istiqomah, N., 2015. Potret Perilaku Hidup Bersih Dan Sehat Masyarakat Pakumbulan Buaran Kabupaten Pekalongan. Jurnal Pena Medika, 5(1). pp.103-109.

Kawalo, A.Y., Ngangi, C.R., Loho, A.E., 2016. Kajian Bertahan Hidup Pemulung Di Tempat Pembuangan Akhir Sampah Kelurahan
Sumompo Kecamatan Tuminting, Manado. ASE, 12(1). pp.47-54.

Kusrini, T., 2015. Perilaku Membuang Sampah Laut Kecamatan Pontianak Tenggara Oleh Masyarakat Ditepian Sungai Kapuas: Studi Kasus di Kelurahan Bangka Belitung Kecamatan Pontianak Tenggara. Jurnal S-1 Sosiologi, 3(3), pp.1-16.

Lee, S., Paik, H.S., 2011. Korean Household Waste Management And Recycling Behavior. Journal Elsevier, 46(5), pp.1159-1166.

Moleong, L., 2012. Metodologi Penelitian Kualitatif. Bandung. PT Remaja Rosdakarya.

Mulasari, S.A., Husodo, A.H., Muhadjir, N., 2016. Analisis Situasi Permasalahan Sampah Kota Yogyakarta Dan Kebijakan Penanggulangannya. Jurnal Kesehatan Masyarakat, 11(2). pp. 96-106

Mulasari, S.A., \& Maani, D., 2013. Hubungan Antara Kebiasaan Penggunaan Alat Pelindung Diri Dan Personal Hygiene Dengan Kejadian Infeksi Kecacingan Pada Pertugas Sampah Di Kota Yogyakarta. Jurnal Ekologi Kesehatan, 12(2). pp.161-170.

Munfiah S., Nurjazuli, \& Onny S., 2013. Kualitas Fisik dan Kimia Air Sumur Gali dan Sumur Bor di Wilayah Kerja Puskesmas Guntur II Kabupaten Demak. Jurnal Kesehatan Lingkungan Indonesia. 12(2), pp.154-159.

Mulasari, S.A., \& Sulistyawati., 2014. Keberadaan TPS Legal dan TPS Ilegal di Kecamatan Godean Kabupaten Sleman. Jurnal KEMAS, 9(2), pp.122-130.

Novianingrum., \& Mulasari, S.A., 2017. Characteristics of Scavengers With Skin Diseases in Wukirsari Landfill, Gunung Kidul, Yogyakarta. Jurnal Kesehatan Masyarakat, 13(2), pp. 224-229.

Peraturan Pemerintah Republik Indonesia Nomor 66 Tahun 2014 Tentang Kesehatan Lingkungan.

Pratama, K.F., \& Prasasti, C.I., 2017. Gangguan Kulit Pemulung di TPA Kenep Ditinjau Dari Aspek Keselamatan Dan Kesehatan Kerja. The Indonesian Journal of Occupational Safety and Health, 6(2). pp.135-145

Riduan, A., 2012. Partisipasi Masyarakat Dalam Pengelolaan Sampah Di Bantaran Sungai Kali Negara Kabupaten Hulu Sungai Utara. Jurnal Socioscientia Kopertis Wilayah XI Kalimantan, 4(2), pp.187-196

Rifat, M.A., Bswas, A., Sufian, H.B., Azad, F., Zahid, M.D.K., 2018. Socio-Economic Status, Hygiene Practices and Microbial Exposure of the Waste Collectors of Dhaka City in Bangladesh. Global Journal of Health Science, 10(12).pp.96-103 
Sinolungan, J.S.V., 2009. Dampak Polusi Partikel Debu Gas Kendaraan Bermotor pada Volume dan Kapasitas Paru. Jurnal Biomedik, 1(2), pp.65-80.

Soemirat, J., 2011. Kesehatan Lingkungan. Yogyakarta. Gajah Mada University Press.

Suhadi, M.Z., \& Namara, I., 2016. Perencanaan Teknis Pembangunan Prasarana Sanitasi (Studi Kasus Pembangunan Prasarana Sanitasi di Kampung Cikukul Desa Nagrak Selatan Kabupaten Sukabumi). Jurnal Rekayasa Sipil ASTONJADRO, 5(2), pp.3545.

Suhartini., 2008. Pengaruh Keberadaan Tempat Pembuangan Akhir (TPA) Sampah Piyungan terdahap Kualitas Air Sumur Penduduk di Sekitarnya. Journal SAINTEK, 1(1), pp.1-17.

Tambunan, M.A., Abidjulu, J., \& Wuntu, A., 2015. Analisis Fisika-Kimia Air Sumur Di Tempat Pembuangan Akhir Sumompo Kecamatan Tuminting Manado. Jurnal MIPA UNSRAT, 4(2), pp.153-156.

Thirarattanasunthon, P., Siriwong, W., Robson, M.,
\& Borjan, M., 2012. Health Risk Reduction Behaviors Model for Scavengers Exposed to Solid Waste in Municipal Dump Sites in Nakhon Ratchasima Province, Thailand. Journal of Risk Management Healthcare Policy, 5, pp.97-104.

Thirarattanasunthon P., Siriwong W., Marija Borjan M., \& Robson M., 2012. Sociodemographic and Environmental Characteristics, and Potential Health Risks of Scavengers in Municipal Dump Sites in Nakhon Ratchasima Province, Thailand. Journal of Health Research, 26(3), pp. 149-153.

Wandansari, A.P., 2013. Kualitas Sumber Air Minum Dan Pemanfaatan Jamban Keluarga Dengan Kejadian Diare. Jurnal KEMAS, 9(1), pp.2429.

Wulandari, C., \& Nasir, N., 2014. Kondisi Bakteriologis Air Sumur di Sekitar Tempat Pembuangan Akhir Air Dingin Kota Padang. Jurnal Biologi Universitas Andalas, 3(4), pp.289-295. 